\title{
Triatoma brasiliensis Neiva, 1911: food sources and diversity of Trypanosoma cruzi in wild and artificial environments of the semiarid region of Ceará, northeastern Brazil
}

Claudia Mendonça Bezerra ${ }^{1,3^{*}}$ (D) Silvia Ermelinda Barbosa², Rita de Cássia Moreira de Souza², Carla Patrícia Barezani², Ricardo Esteban Gürtler ${ }^{4}$, Alberto Novaes Ramos Jr. ${ }^{1}$ and Liléia Diotaiuti ${ }^{2}$

\begin{abstract}
Background: Knowledge of triatomine food sources in different ecotopes enables the estimation of T. cruzi transmission risk in diverse environments, as well as its dynamics of dispersion and ecological niche. For Triatoma brasiliensis in the Caatinga, in the northeast of Brazil, seasonal differences influence feeding eclecticism and rates of $T$. cruzi infection. The objective of the present study was to monitor food sources and to characterize the populations of T. cruzi associated with T. brasiliensis in wild and domestic environments in the Caatinga of northeast Brazil.

Methods: A cross-sectional study based on a search for triatomines in wild and domestic environments, was undertaken at five different time periods from 2009 to 2015. Insects from 2015 were used for identification of food sources. Two universal primers, based on the conserved regions of the 125 rRNA locus, were used to amplify fragments of $215 \mathrm{bp}$. The content of the intestinal tract of triatomines was identified by a comparison between the sequences obtained and those deposited in the GenBank database, using BLAST. In triatomines with parasitological diagnosis of infection by trypanosomatids, xenoculture was performed for the isolation and characterization of strains, using cox2, the amplification of the SL-IL mini-exon intergenic spacer and the polymorphism of the D7 divergent domain of the gene 24arDNA-LSU.
\end{abstract}

Results: Food sources were identified in 76.3\% (213/279) T. brasiliensis specimens sampled in 2015. The most frequent sources in a total of 20 vertebrate species were: rodents $(58 \%, 123 / 213)$, ruminants $(30 \%, 64 / 213)$ and cats $(6 \%, 12 / 213)$. A total of 49\% (44/89) of the samples of T. cruzi isolated in the period from 2009 to 2015 were characterized: Tcll (43\%, 19/44), TCl (41\%, 18/44) and TCIII (16\%, 7/44).

Conclusions: The feeding eclecticism of $T$. brasiliensis shows its importance in maintaining the transmission dynamics of T. cruzi, with evidence of intense circulation between anthropic and wild environments. Attention should be placed on the association among T. brasiliensis, rodents and ruminants, in addition to the presence of Tclll in the study region.

Keywords: Chagas disease, Triatoma brasiliensis, Trypanosoma cruzi, Discrete typing unit, Eating behavior, Caatinga, Brazil

* Correspondence: cmendoncab@gmail.com

${ }^{1}$ Universidade Federal do Ceará, Departamento de Saúde Comunitária,

Faculdade de Medicina, Fortaleza, CE, Brasil

${ }^{3}$ Secretaria da Saúde do Estado do Ceará, Fortaleza, CE, Brasil

Full list of author information is available at the end of the article

(C) The Author(s). 2018 Open Access This article is distributed under the terms of the Creative Commons Attribution 4.0 International License (http://creativecommons.org/licenses/by/4.0/), which permits unrestricted use, distribution, and reproduction in any medium, provided you give appropriate credit to the original author(s) and the source, provide a link to the Creative Commons license, and indicate if changes were made. The Creative Commons Public Domain Dedication waiver (http://creativecommons.org/publicdomain/zero/1.0/) applies to the data made available in this article, unless otherwise stated. 


\section{Background}

Chagas disease is a neglected chronic infectious disease that persists with high rates of morbidity and mortality. Approximately 6-7 million people are infected worldwide and the disease causes 12,000 deaths/year [1-3]. Its magnitude and transcendence reinforces the fact that it is a priority as a public health problem in Brazil [3].

Trypanosoma cruzi (Protozoa: Sarcomastigophora: Kinetoplastida: Trypanosomatidae) [4], the etiological agent of Chagas disease, has high adaptive success, with different degrees of tissue tropism, virulence and susceptibility to drugs. It has a broad host range which includes more than 150 species of mammals. It can colonize virtually any tissue of these vertebrates, and it may be transmitted by dozens of species of triatomines (Hemiptera: Reduviidae: Triatominae) [5-8].

Trypanosoma cruzi is composed of heterogeneous populations classified into seven DTUs (discrete typing units): TcI-TcVI $[9,10]$ and TcBat, which are associated with bats and genetically similar to TcI [11]. The first six DTUs can also cause infections and diseases in humans. However, the prevalence and dispersion of these DTUs differ according to geographical and ecological niches, with variations in clinical epidemiology $[9,12]$.

Triatomines, obligatory hematophagous hemipterans of the family Reduviidae (subfamily Triatominae), are subdivided into five tribes and more than 150 species [13]; of these, 65 (44\%) occur in Brazil [14, 15]. In the Caatinga, an exclusively Brazilian biome, there is a high triatomine diversity, with $18(27 \%)$ of the species recorded in Brazil [15-17]. Theoretically, all triatomine species are considered capable of transmitting the six $T$. cruzi lineages described [18], participating in the maintenance of the enzootic cycle or domestic cycles $[19,20]$.

Three subspecies of Triatoma brasiliensis have been recognized [21]: T. brasiliensis brasiliensis Neiva, 1911; T. brasiliensis melanica Neiva \& Lent, 1941; and T. brasiliensis macromelasoma Galvão, 1956. In 1979, Lent \& Wygodzinsky [22] considered the three subspecies as synonyms for $T$. brasiliensis and claimed that the differences among them were only chromatic. In 2006, the subspecies $T$. $b$. melanica was elevated to the species rank as Triatoma melanica [23]. The same occurred with Triatoma juazeirensis in 2007 [24], cited by Lent \& Wygodzinsky [22] as a dark variant of T. brasiliensis. Thus, the $T$. brasiliensis complex currently includes two subspecies (T. brasiliensis brasiliensis and T. b. macromelasoma [25]) and six species (T. lenti, T. juazeirensis, T. melanica, T. bahiensis [26], T. sherlocki [27] and T. petrocchiae [14, 28].

Triatoma brasiliensis brasiliensis Neiva, 1911, hereby referred to as Triatoma brasiliensis, is the main species responsible for T. cruzi transmission in the Northeast region of Brazil. Its center of dispersion is related to the
Caatinga biome [29]. In wild environments (particularly in rock outcrops) there are colonies with high infection rates associated with several species of bats, marsupials and rodents [30-32]. In sedimentary plains, these insects can be associated with the cactus Pilosocereus gounellei [33].

From the recognized geographical distribution of $T$. brasiliensis, analyses of usual entomological indicators showed the epidemiological importance of the species in Bahia (BA), Ceará (CE), Piauí (PI), Paraíba (PB), Pernambuco (PE) and Rio Grande do Norte (RN) states, emphasizing their high rates of intradomicile infestation, high population density and variable percentages of natural infection by trypanosomatids [34, 35].

In Ceara State, T. brasiliensis was initially recognized in 1922 by Neiva \& Pinto, in the Jaguaribe mesoregion. From 1955 to 1983, this species was found present in $86 \%(121 / 141)$ of the municipalities of Ceará, with $44 \%$ (62/141) of specimens infected with T. cruzi [30]. Technical reports from the Health Department of Ceará State show that between 2000-2017, 289,907 specimens of $T$. brasiliensis were captured in $87 \%(161 / 184)$ of the municipalities in the state, with natural infection with trypanosomatids in $65 \%(119 / 184)$ of these areas.

In extreme natural conditions, in order to obtain a blood meal, $T$. brasiliensis exceeds microclimatic preferences established in the laboratory [36], and it is able to fiercely attack humans and animals, even during daylight $[37,38]$. Feeding eclecticism and opportunism are striking characteristics of triatomines, which can suck blood from a wide variety of vertebrates [39]. Understanding these aspects in anthropic environments can support strategies for vector control, especially in species such as $T$. brasiliensis, which represent an important operational challenge. This fact occurs in view of the constant recolonization of intra- and peridomiciles that can occur as a result of natural foci or specimens which remain after chemical control [36, 37, 40-43].

Food availability is a determinant factor for the size of triatomine populations in various ecotopes [44]. In this context, the anthropic environment provides not only a great availability of food sources but also a wide range of shelter. For this reason, survivors of the peridomiciliar colonies are frequent, contributing to reinfestation of the domestic environments [32].

The feeding eclecticism of $T$. brasiliensis has already been reported in different studies $[45,46]$. This species is capable of feeding on humans, dogs and cats in artificial environments or natural ecotopes [30]. Blood of rodents, reptiles, mammals and birds were identified as food sources in samples of the stomach contents of wild T. brasiliensis specimens [47]. There have also been 
reports that seasonal differences influence feeding eclecticism as well as rates of infection with $T$. cruzi [48]. The latter study found a decrease in the quantity of food sources identified when droughts lasted longer. Another finding was that the main food sources of $T$. brasiliensis were birds (33.1\%) and armadillos (18.8\%). The extensive farming of chickens and goats in the Brazilian state of Ceará was highlighted as a factor of connection between anthropic and wild environments [49]. DNA sequences of chickens (50\%) and goats (29\%) were identified in samples of the stomach contents of triatomines from a wild environment, since they are often found in these environments. Thus, knowledge of triatomine food sources in different ecotopes assists in estimating the risk of transmission of $T$. cruzi in diverse environments, as well as its dynamics of dispersion and ecological niche $[40,50]$. In this perspective, the objective of the present study was to monitor food sources and to characterize $T$. cruzi populations associated with $T$. brasiliensis in wild, intradomicile and peridomicile environments in the Caatinga, in Tauá municipality of Ceará State, in the Northeast Brazil region.

\section{Methods}

\section{Research design and study site}

This is a descriptive ecological study conducted in Tauá municipality, in Ceará State (Fig. 1), a region of epidemiological and historical importance in the context of the vectorial transmission of Chagas disease, with high levels of infestation by triatomines, and predominance of T. brasiliensis [34, 49, 51].

Tauá is located in the hinterland of Inhamuns $\left(6^{\circ} 00^{\prime} 11^{\prime \prime S}\right.$, $\left.40^{\circ} 17^{\prime} 34^{\prime \prime} \mathrm{W}\right)$ at an altitude of $402.7 \mathrm{~m}, 320 \mathrm{~km}$ from Fortaleza. The average annual temperature ranges from $26^{\circ} \mathrm{C}$ to $28{ }^{\circ} \mathrm{C}$ and the average annual rainfall is $597.2 \mathrm{~mm}^{3}$, with the rainy period between February and April [52].

The shrub-arboreal Caatinga is the predominant vegetation, especially thorny deciduous vegetation, associated with rock soils with expressive fractures and extreme water deficiency in for most of the year [53]. The granite rocks provide shelter to small mammals, reptiles and insects, including $T$. brasiliensis, which has this environment as its natural habitat [29].

A search for triatomines was performed in 252 housing units (HU) of 18 rural localities (Fig. 1), where the
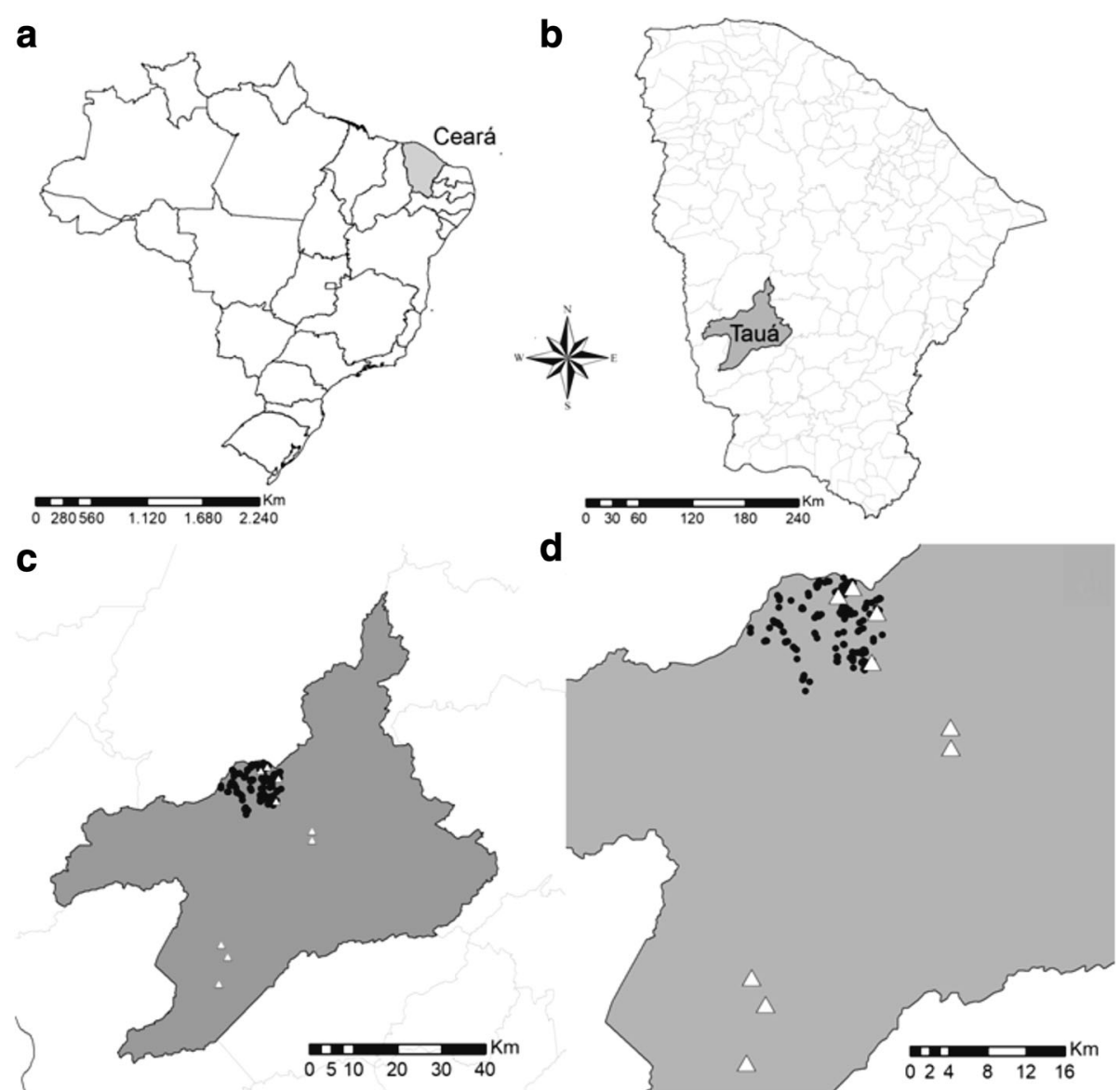

Fig. 1 a Location of Ceará State, Brazil. b Area of Tauá munipality, Ceará, Brazil. c Study site. d Detail of study site. Circles indicate anthropic environments; triangles indicate wild environments. Source: adapted from Google Earth and QGis 2.14. Essen 
last residual chemical control for triatomines had occurred 24 months before. These HUs were investigated in five periods (February 2009, August 2009, March 2010, October 2010 and August 2015), in order to ensure representativeness of the seasonality which is typical of Ceará State. The search was carried out manually, as advocated by the Technical Standards Manual (1980) [54], by municipal staff for the control of endemic diseases. They were supervised by the Ceará State Health Secretariat (SESA-CE) and used appropriate forms as a data collection instrument (Additional file 1). The search was performed exhaustively, i.e. through all the rooms of the households and peridomicile ecotopes, seeking to capture all insects found. HU represents the epidemiological unit of reference in vector control, formed by the whole set of the human dwelling and its surroundings with all permanent and temporary buildings, accumulations of materials, fences, animal shelters, etc. [54]. The intradomicile was considered as a single space, and the peridomicile was divided into types of annexes: (i) chicken coop; (ii) pigsty; (iii) barn; (iv) firewood; (v) stone, brick and roofing tile; and (vi) other.

The ecotopes of the triatomines captured in the peridomicile were marked, allowing the description of families of vertebrate animals, identified as food sources according to developmental instar and specific place of capture. When the peridomicile ecotopes were categorized, the importance of "roofing tiles, bricks and stones" and "firewood" was recognized. Therefore, a decision was made to include in the analysis the location of these structures in the peridomicile. Records were made whether they were within the structures built to house economically important synanthropic animals, for example, "pens", or if they were randomly dispersed in the environment.

In parallel and within the corresponding area to the search of infestation in the $\mathrm{HU}$, the search for wild triatomines populations was conducted in three areas with rock formations that could be natural shelters of $T$. brasiliensis. These areas are located at variable distances from human dwellings. In the search conducted in August 2015, the wild capture area was expanded to other six places in the municipality with similar characteristics to those of the previously defined areas (Fig. 1).

\section{Laboratory tests}

Captured triatomines were initially identified to the species level [22, 25], place of capture and developmental instar. Fresh feces, obtained by abdominal compression, were examined to determine infection with trypanosomatids with an optical microscope $(400 \times)$. The intestinal contents of most positive triatomines were placed in culture medium for the isolation of strains [55].
Food sources were identified by using insects captured in August 2015. They were kept in cryogenic vials containing $70 \%$ ethyl alcohol and frozen at $-20{ }^{\circ} \mathrm{C}$ until analysis. Procedures for parasitological diagnostic of feces were conducted in the Laboratories of Entomology Dr Tomaz Aragão, Ceará State, Health Secretariat (SESA-CE) and the Reference Laboratory in Triatomines and Epidemiology of Chagas Disease of the René Rachou Institute (IRR)/Fiocruz Minas. Molecular characterization of parasites and determination of food sources of the triatomines were performed by the IRR.

\section{Identification of food sources}

The extraction of stomach contents used only adult insects and fifth-instar nymphs. The remaining stages were not used because the insects had little blood in the digestive tube and thus a low chance of presenting conclusive results. For exposure of the digestive tube, insects were dissected; the wings of adults were removed, and in both stages, the conexivum was removed, thus allowing the separation of the dorsal and ventral cuticles of the abdomen of the insects. Digestive tube was separated and placed in microtubes containing $70 \%$ ethanol. It should be noted that the stomach contents of the insects were only removed if, when dissected, they clearly showed food contents in the digestive tract.

\section{PCR amplification and direct sequencing of the 125 rRNA locus}

Total DNA extraction from triatomine digestive tract content used the protocol of the DNeasy Blood and Tissue $\mathrm{Kit}^{\text {tw }}$ (Qiagen, Hilden, Germany). Two universal primers for vertebrate animals designed based on the conserved regions of the $12 S$ locus of the rRNA (L1085 5'-CCC AAA CTG GGA TTA GAT ACC C-3' and H1259 5'-GTT TGC TGA AGA TGG CGG TA-3') which amplified a fragment of 215 bp [56].

PCR was performed in a final volume of $25 \mu \mathrm{l}$, containing 40-50 ng of genomic DNA, $2.5 \mu \mathrm{l}$ of buffer $10 \times, 2.5 \mu \mathrm{l}$ of dNTP $2.5 \mathrm{Mm}, 0.75 \mu \mathrm{l}$ of $\mathrm{MgCl}_{2} 50 \mathrm{mM}, 2.5 \mu \mathrm{l}$ of each primer $(10 \mathrm{pmol})$ and $0.25 \mu \mathrm{l}$ of Taq Platinum $0.5 \mathrm{U} / \mu \mathrm{l}$ (Invitrogen, California, USA). For each PCR reaction, a negative control (without DNA) was run in parallel.

PCR was conducted in 35 cycles of $95^{\circ} \mathrm{C}$ for $30 \mathrm{~s}, 57^{\circ}$ $\mathrm{C}$ for $15 \mathrm{~s}$ and $72{ }^{\circ} \mathrm{C}$ for $30 \mathrm{~s}$ using a Veriti ${ }^{\mathrm{mw}}$ thermal cycler (Applied Biosystems, Foster City, CA, USA). Amplified products were observed in $8 \%$ polyacrylamide gel stained with silver nitrate $0.2 \%$.

The products of the positive samples after PCR were purified using a QIAquick PCR Purification Kit ${ }^{\mathrm{m}}$ (Qiagen), according to the manufacturer's protocol. Purified PCR products were sequenced using a BigDye Terminator v.3.1 Cycle Sequencing $\mathrm{Kit}^{\mathrm{tm}}$ and an ABI 3730XL DNA Analyzer ${ }^{\mathrm{mw}}$, both from Applied Biosystems. 


\section{Identification of sequences}

To identify the food sources of the triatomines being analyzed, the resulting sequences were compared with sequences deposited into the GenBank database by using the search tool through the software BLASTn (https:// blast.ncbi.nlm.nih.gov/Blast.cgi).

\section{Characterization of $T$. cruzi according to DTUs Samples}

After the parasitological diagnosis had been confirmed, parasites were kept in liquid culture (liver infusion tryptose, LIT). The samples that showed fungal contamination were discarded. The others were maintained in a state of exponential growth to obtain approximately $10^{5}$ parasites $/ \mathrm{ml}$ of culture. DNA was extracted by the phenol-chloroform method as described by Vallejo et al. [57].

\section{Triple assay}

The classification of DNA samples of T. cruzi was based on the protocol proposed by Davilla et al. [58]. This scheme proposes a classification considering the mitochondrial gene cytochrome $c$ oxidase subunit 2 (cox2) [59], the amplification of the mini-exon intergenic spacer of T. cruzi [60], and the polymorphism of the D7 divergent domain of the gene 24arDNA - LSU rDNA [61]. All reactions were carried while using positive and negative controls. Fragments generated by the amplification of the genes $24 \alpha \mathrm{rDNA}$ and $\operatorname{cox} 2$ were visualized on polyacrylamide gel at $6 \%$ with silver staining. The amplified product from the mini-exon was visualized on $2 \%$ agarose gel. Gel Red Nucleic Acid Stain 1:300 (Biotium, Fremont, CA, USA) was used as a fluorescent marker of the amplified band.

\section{Spatialization of $T$. cruzi populations}

Geographical coordinates of the positive ecotopes for the presence of triatomines were recorded along the activities with the aid of a Garmin eTrex ${ }^{\mathrm{Tm}}$ 12-channel GPS, with WGS89 - Zone 24S projection. Subsequently, points were geocoded in high resolution, in accordance with the basis of Google Earth Pro ${ }^{\circledR}$ software v.7.1, generating a map embedded in the environment of the geographical information system (GIS). After that, the exploratory analysis of spatial behavior of events was based on the estimated kernel density to create a raster map whereby the density was based on the number of points in the study region. In this way, it was checked whether the events occurred at random or there were aggregations among them (hotspots), indicating the occurrence of clusters [62]. For the thematic map of the distribution of $T$. cruzi populations, a radius of $700 \mathrm{~m}$ was considered, generated in the software QGis v.2.14, an open-source geographical information system (https://qgis.org/en/site/about/index.html).

\section{Statistical analysis}

Rates of infestation and colonization were calculated based on the housing units (intradomicile and peridomicile) with the presence of triatomines in the searched units. Natural infection refers to triatomines parasitized by trypanosomatids in the examination of fresh feces. The association among habitat, blood source (or host) and parasite genotype was checked by using Fisher's exact test and Pearson's test, with a statistical significance of $0.05 \%$. The analyses were performed in the software Stata v.15.1. (StataCorp LP, College Station, TX, USA).

\section{Results}

The results of the five catches in the study period are shown in Additional file 2: Table S1; 66.4\% (1928/2906) of the triatomines found in the housing units were identified as T. brasiliensis and 33.4\% (971/2906) as Triatoma pseudomaculata. In the wild environment, $1077 \mathrm{~T}$. brasiliensis specimens were captured. The natural infection indices found for trypanosomatids were: intradomicile (10.3\%, 18/175); wild environment (3.3\%, 32/979); and peridomicile $(3.1 \%, 51 / 1629)$.

\section{Food sources}

Of the 279 samples processed for the identification of the food source of triatomines, 194 (69.5\%) presented identity greater than or equal to $95 \%$ when compared to the sequences in GenBank. Identities of 90-94\% were found in $19(8.6 \%)$ samples, in a total of 213 samples (76.3\%) with satisfactory results. Most of these triatomines $(46.5 \%, 99 / 213)$ were captured in the peridomicile. The developmental instar with the highest representation in the sample was nymph N5 (35.2\%, 75/213) (Table 1; Additional file 2: Tables S2 and S3). Twenty species of animal were distributed into 13 families, of which 10 (76.9\%) were from wild triatomines, 10 (76.9\%) from peridomicile and 9 (69.2\%) from intradomicile environments (Table 2; Additional file 2: Table S3).

Although rodents $(57.8 \%, 123 / 213)$ and goats $(21.1 \%$, $45 / 213$ ) were the most frequent food sources in all environments, there was no statistically significant difference

Table 1 Number of Triatoma brasiliensis sampled for characterization of food sources in accordance with place of capture and developmental stage, in Tauá municipality, Ceará, Brazil, 2015

\begin{tabular}{lllll}
\hline Environment & $\begin{array}{l}\text { Nymph 5 } \\
n(\%)\end{array}$ & $\begin{array}{l}\text { Male } \\
n(\%)\end{array}$ & $\begin{array}{l}\text { Female } \\
n(\%)\end{array}$ & $\begin{array}{l}\text { Total } \\
n(\%)\end{array}$ \\
\hline Peridomicile & $27(27.3)$ & $28(28.3)$ & $44(44.4)$ & $99(100)$ \\
Wild & $46(53.5)$ & $24(27.9)$ & $16(18.6)$ & $86(100)$ \\
Intradomicile & $2(7.1)$ & $17(60.7)$ & $9(32.1)$ & $28(100)$ \\
Total & $75(35.2)$ & $69(32.4)$ & $69(32.4)$ & $213(100)$ \\
\hline
\end{tabular}


Table 2 Food sources of Triatoma brasiliensis in the anthropic and wild environments, identified by PCR with primers (L1085 and H1259) projected with a basis on the conserved regions of the 12S rRNA locus, in Tauá municipality, Ceará, Brazil, 2015

\begin{tabular}{|c|c|c|c|c|c|}
\hline Class & Order & Family & Species & GenBank ID & Associated environment \\
\hline \multirow[t]{16}{*}{ Mammalia } & \multirow[t]{9}{*}{ Rodentia } & \multirow[t]{3}{*}{ Echimyidae } & Proechimys cuvieri & KU892778.1 & \multirow[t]{3}{*}{$W, I, P$} \\
\hline & & & Proechimys roberti & KU892772.1 & \\
\hline & & & Thrichomys apereoides & KU892773.1 & \\
\hline & & \multirow[t]{2}{*}{ Caviidae } & Galea spixii & AF433913.1 & \multirow[t]{2}{*}{ W, I, P } \\
\hline & & & Kerodon rupestris & AY765988.1 & \\
\hline & & \multirow[t]{2}{*}{ Cricetidae } & Wiedomys cerradensis & KF769457.1 & \multirow[t]{2}{*}{$W, I, P$} \\
\hline & & & Oecomys bicolor & KX381448.1 & \\
\hline & & \multirow[t]{2}{*}{ Muridae } & Rattus rattus & KX381445.1 & \multirow[t]{2}{*}{$P$} \\
\hline & & & Mus musculus & KX381752.1 & \\
\hline & \multirow[t]{4}{*}{ Artiodactyla } & \multirow[t]{2}{*}{ Bovidae } & Bos taurus & КT343749.1 & \multirow[t]{2}{*}{ W, I, P } \\
\hline & & & Capra hircus & KY305183.1 & \\
\hline & & Suidae & Sus scrofa & KT194220.1 & I, P \\
\hline & & Capridae & Ovis aries & KR868678.1 & $W, I, P$ \\
\hline & Didelphimorphia & Didelphidae & Monodelphis domestica & AJ508398.1 & W, I \\
\hline & Perissodactyla & Equidae & Equus cabalus & KX669268.1 & I \\
\hline & Carnivora & Felidae & Felis silvestris & KX002032.1 & $W, I, P$ \\
\hline \multirow[t]{4}{*}{ Aves } & \multirow[t]{2}{*}{ Psittaciformes } & \multirow[t]{2}{*}{ Psittacidae } & Pionus menstruus & KX925978.1 & \multirow[t]{2}{*}{$W, P$} \\
\hline & & & Forpus crassirostris & DQ143215.1 & \\
\hline & \multirow[t]{2}{*}{ Galliformes } & \multirow[t]{2}{*}{ Phasianidae } & Meleagris gallopavo & $J F 275060.1$ & \multirow[t]{2}{*}{ W, P } \\
\hline & & & Gallus gallus & KX781319.1 & \\
\hline Reptilia & Squamata & Phyllodactylidae & Phyllopezus pollicaris & KJ484234.1 & W \\
\hline
\end{tabular}

Abbreviations: $W$ wild, $I$ intradomicile, $P$ peridomicile

between the animal group identified as a food source and the ecotope where triatomine was captured (Pearson's Chi-square test: $\chi^{2}=11.3801, d f=6, P=0.77$; Fisher's exact test: $P=0.06$ ) (Table 3 ). In addition to these two groups, cattle and cats were also identified in

Table 3 Animals identified as food sources of Triatoma brasiliensis according to capture environment, Tauá, Ceará, Brazil, 2015

\begin{tabular}{lllll}
\hline Animal group & $\begin{array}{l}\text { Intradomicile } \\
n(\%)\end{array}$ & $\begin{array}{l}\text { Peridomicile } \\
n(\%)\end{array}$ & $\begin{array}{l}\text { Wild } \\
n(\%)\end{array}$ & $\begin{array}{l}\text { Total } \\
n(\%)\end{array}$ \\
\hline Rodents & $15(54)$ & $53(54)$ & $55(64)$ & $123(58)$ \\
Goats & $5(18)$ & $27(27)$ & $13(15)$ & $45(21)$ \\
Cattle & $3(11)$ & $12(12)$ & $4(5)$ & $19(9)$ \\
Cats & $2(7)$ & $2(2)$ & $8(9)$ & $12(6)$ \\
Birds & - & $4(4)$ & $2(2)$ & $6(3)$ \\
Marsupials & $1(4)$ & - & $3(3)$ & $4(2)$ \\
Pigs & $1(4)$ & $1(1)$ & - & $2(1)$ \\
Horses & $1(4)$ & - & - & $1(0)$ \\
Reptiles & - & - & $1(1)$ & $1(0)$ \\
Total & $28(100)$ & $99(100)$ & $86(100)$ & $213(100)$ \\
\hline $\begin{array}{l}\text { Pearson's Chi-square test: } \chi^{2}=11.3801, d f=6, P=0.77 ; \text { Fisher's exact } \\
\text { test: } P=0.06\end{array}$ & \multicolumn{4}{l}{}
\end{tabular}

the study environments. Of the seven groups of animals identified in the wild and intradomicile environments, five were coincident: rodents, goats, cats, cattle and marsupials. DNA samples of horses and pigs were identified in the intradomicile; they were both related to adult $T$. brasiliensis males. The intradomicile sample of marsupial DNA belonged to a female T. brasiliensis specimen. Of the groups of animals characterized in the peridomicile and wild environment, blood samples of marsupials and reptiles were present in triatomines, while pigs were characterized only for insects found in the peridomicile. In the housing units, birds were characterized only in the peridomicile, while marsupials and horses were only described in the intradomicile. The only human DNA sample was recorded in a nymph N5 in the peridomicile, but its similarity was $88 \%$ when compared with sequences on GenBank; therefore, it was regarded as negative (Table 3).

\section{Ecotopes}

Triatomines captured in "roofing tiles, bricks and stones" accounted for the largest part of the sample (54.5\%), as well as for the greatest diversity of families of vertebrate animals identified as a food source. Adult 
triatomines were those which had the largest number of food sources identified $(n=72)$, present in all peridomicile ecotopes described in this study. Nymphs N5 were sampled at only four ecotopes, but they had greater diversity of associated food sources $(n=6)$ (Table 4). For the purpose of analysis, animal groups were simplified to rodents, goats and other (sum of other groups). The same procedure was adopted for the sampled triatomines, i.e. nymphs and adults were grouped together. The analysis showed that there is a statistically significant difference between the group of animals identified as a food source in comparison to the peridomicile ecotope in which triatomines were caught (Pearson's Chi-square test: $\chi^{2}=17.8224, d f=8, P=0.023$; Fisher's exact test: $P=0.02$ ). Rodents are the most expressive food sources in roofing tiles, bricks and stones while rodents and goats are equally important in "sheepfolds".

\section{Characterization of $T$. cruzi}

Altogether, 101 triatomines had been infected with trypanosomatids, as shown by parasitological examination of fresh feces, of which $87.1 \%$ (88/101) had isolated parasites, of which $48.9 \%$ (43/88) were characterized. A sample of TcIII was characterized after the capture of $M$. domestica [47] (1/88) (Table 5).

Of the discarded samples, $51.1 \%(45 / 88)$ had been contaminated by fungi, while in $12.8 \%(13 / 101)$ of triatomines with positive parasitological examination, the parasite could not be isolated because it did not have enough intestinal content for the purposes of culture. The poor nutritional status of triatomines hampered the identification of the food source of those which were infected.

The environment of housing units had the largest number of characterized T. cruzi populations (73\%, 32/ $44)$; peridomicile accounted for $63.6 \%(28 / 44)$ of the samples. "Roofing tiles, bricks and stones" corresponded to peridomicile ecotopes which had the highest number of characterized T. cruzi populations (50\%, 14/28). In total, $43.2 \%(19 / 44)$ of the samples corresponded to TcII, $40.9 \%(18 / 44)$ to TcI and $15.9 \%(7 / 44)$ to TcIII (Table 5, Figs. 2 and 3).

Spatial analysis identified four main clusters of T. cruzi populations distributed in different environments (Fig. 3). Peridomicile contributed to the formation of all of them. TcI was described in clusters 1 (roofing tiles), 2 (pigsty, roofing tiles and firewood) and 4 (sheepfold). In addition, in the peridomicile, TcII was found in clusters 3 (bricks) and 4 (chicken coop). Wild environment (stones) contributed in clusters 1 (TcIII) and 3 (TcII). Intradomicile has participated in the formation of cluster 4 , with the TcI population of T. cruzi. This way, the following parasites were identified: those characterized as TcI and TcIII in the intradomicile environment, as TcI and TcII in the peridomicile, and as TcII and TcIII in the wild environment.

\section{Discussion}

The results show a wide distribution of $T$. brasiliensis specimens in the analyzed locations and occupying natural or artificial ecotopes. The evaluation of the feeding behavior of this vector in artificial (anthropic environment) and wild ecotopes acknowledges its close relationship with rodents, goats, cats and cattle. In the samples from the wild environment, DNA was identified from ten families of vertebrates, including marsupials, birds, reptiles, goats, sheep, cattle, cats and chickens. The recognition of nymphs fed with the blood of domestic animals, in view of their limited mobility, shows the importance of these animals, which move along the wild environment as a source of food for T. brasiliensis in its natural ecotope.

The detection of DNA of marsupials in intradomicile triatomines signals the risk of transmission of the parasite to humans because they have recognized synanthropic activity and often present high rates of natural infection by $T$. cruzi. Historically, the species of the family Didelphidae are recognized as a "bridge" between the wild and domestic cycles of T. cruzi [63-67].

In most adult triatomines caught in the intradomicile, the DNA of nine families of vertebrate animals was identified, especially wild animals and economically important animals reared in semi-extensive farming systems in the peridomicile environment. The contact with different food sources demonstrates the intense mobility of T. brasiliensis [39], which results in the colonization of the artificial environment [68]. As for nymphs, DNA samples from cats and goats, animals which circulate in the intradomicile in the study area, were characterized. We also found triatomines that had fed on the blood of goats in the intradomicile likely because the local population rears offspring of these animals inside the household when they are abandoned by their mothers.

Three families (Echimyidae, Caviidae and Cricetidae) of wild rodents which are considered to be natural hosts of $T$. cruzi were characterized in triatomines captured in all the study environments (Table 2). Considering the food sources identified in this study and the abundance of the rodents, it can be inferred that these mammals are the main food sources of triatomines. Moreover, they probably also have the role of primary reservoir of T. cruzi in the region, as found in previous studies $[49,69,70]$.

In addition to rodents, cats and goats/sheep represented important food sources for $T$. brasiliensis in natural and domestic ecotopes, which can also be a link between domestic and wild cycles of $T$. cruzi. In the literature, cats are recognized as an important food source of triatomines [30, 45, 69, 71]; furthermore, they 


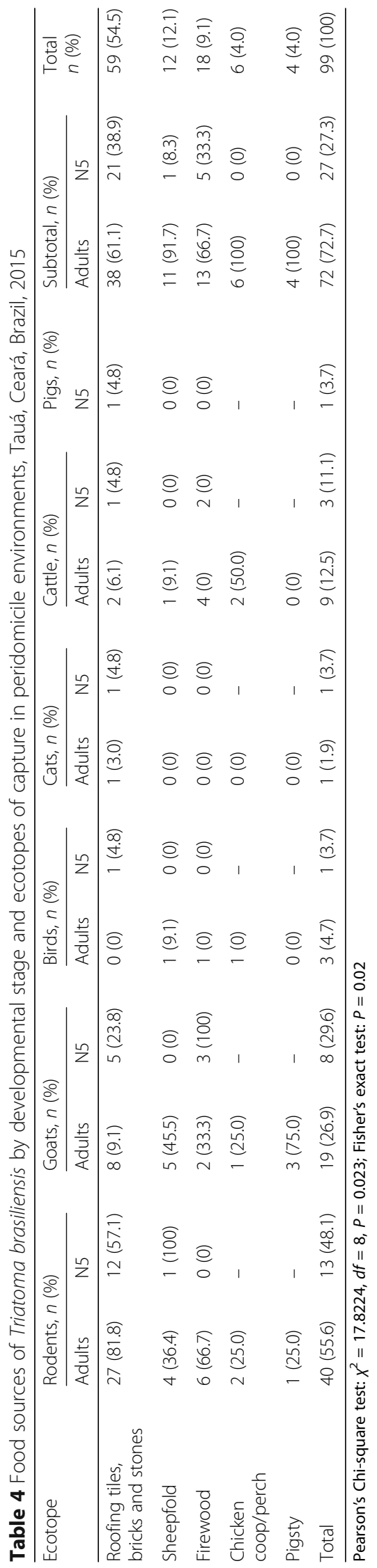


Table 5 Characterization of Trypanosoma cruzi using the amplification of cox2, of the mini-exon intergenic spacer (SL-IL) and polymorphism of the D7 divergent domain of the gene 24arDNA-LSU rDNA, Tauá municipality, Ceará, Brazil, 2009 to 2015

\begin{tabular}{|c|c|c|c|c|c|c|c|}
\hline Period & Place of capture & Ecotope & Associated species & No. of samples & $\mathrm{TCl}$ & Tcll & Tclll \\
\hline \multirow[t]{5}{*}{ February 2009} & Peridomicile & Bricks & T. brasiliensis & 6 & - & 6 & - \\
\hline & & Stones & T. brasiliensis & 1 & - & 1 & - \\
\hline & & Firewood & T. brasiliensis & 5 & 5 & - & - \\
\hline & Wild & Stones & T. brasiliensis & 2 & - & 1 & 1 \\
\hline & $n$ & & & 14 & 5 & 8 & 1 \\
\hline \multirow[t]{2}{*}{ August 2009} & Wild & Stones & T. brasiliensis & 6 & - & 6 & - \\
\hline & $n$ & & & 6 & - & 6 & 0 \\
\hline \multirow[t]{6}{*}{ March 2010} & Intradomicile & Intradomicile & T. brasiliensis & 2 & 1 & - & 1 \\
\hline & Peridomicile & Roofing tiles & T. brasiliensis & 2 & 1 & 1 & - \\
\hline & & Sheepfold & T. brasiliensis & 1 & 1 & - & - \\
\hline & & Chicken coop & T. brasiliensis & 2 & - & 2 & - \\
\hline & Wild & Stones & Monodelphis domestica ${ }^{a}$ & 1 & - & - & 1 \\
\hline & $n$ & & & 8 & 3 & 3 & 2 \\
\hline \multirow[t]{4}{*}{ October 2010} & Intradomicile & Intradomicile & T. brasiliensis & 1 & 1 & - & - \\
\hline & Peridomicile & Pigsty & T. brasiliensis & 4 & 4 & - & - \\
\hline & & Roofing tiles & T. brasiliensis & 3 & 2 & 1 & - \\
\hline & $n$ & & & 8 & 7 & 1 & - \\
\hline \multirow[t]{7}{*}{ August 2015} & Intradomicile & Intradomicile & T. brasiliensis & 1 & - & - & 1 \\
\hline & Peridomicile & Chicken coop & T. pseudomaculata & 1 & - & 1 & - \\
\hline & & Roofing tiles & T. brasiliensis & 2 & 2 & - & - \\
\hline & & Firewood & T. brasiliensis & 1 & 1 & - & - \\
\hline & Wild & Stones & T. brasiliensis & 3 & - & - & 3 \\
\hline & $n$ & & & 8 & 3 & 1 & 4 \\
\hline & $N$ & & & 44 & 18 & 19 & 7 \\
\hline
\end{tabular}

${ }^{\mathrm{a} B e z e r r a ~ e t ~ a l . ~[47] ~}$

Abbreviations: Tcl T. cruzi I, Tcll T. cruzi II, TcIII T. cruzi III, $n$, subtotal: $N$, total

maintain populations of T. cruzi [69]. Although goats/ sheep are often cited as food sources for T. brasiliensis in the semi-arid Northeast region [47, 49, 65, 70, 72], there are still important knowledge gaps on the actual role of these animals in the epidemiology of Chagas disease in the region, especially if the economic representation of these animals is taken into consideration. Meat, milk, viscera and leather of these animals are marketed, often in natura.

The identification of Felis silvestris (a species that does not occur in Brazil) as a food source for T. brasiliensis in this study is likely due to the limitation of GenBank for the identification of sequences, and it is believed that the animal corresponds to Felis domesticus, which is very common in the region. Absence of specific sequences, DNA fragmentation by degradation and a description of mixed food sources are methodological gaps that still need to be overcome.

Despite the high dispersion of triatomines in evaluated environments, human DNA was not detected in the samples of the captured vectors. This result may indicate some kind of self-protection of this community to minimize the contact with triatomines; of note, numerous studies have shown the intimate and persistent relation between $T$. brasiliensis and humans [30, 32, 39, 40, 42, 43, 46, 47, 49, 70].

The peridomicile represents a complex set of ecotopes (artificial and natural) that sometimes overlap, thus forming a network of ecological niches that interact, depending on human intervention and climatic conditions. Shelters in peridomicile annexes favor the establishment and proliferation of triatomine colonies, but this phenomenon does not occur consistently in time and space because these structures are usually transient and renewable. Thus, some artificial ecotopes have been shown to be more attractive than others for the development of these insects $[42,73,74]$.

The results of this study show the importance of "roofing tiles, bricks and stones", because in addition to the abundance of insects sampled in these ecotopes, the 

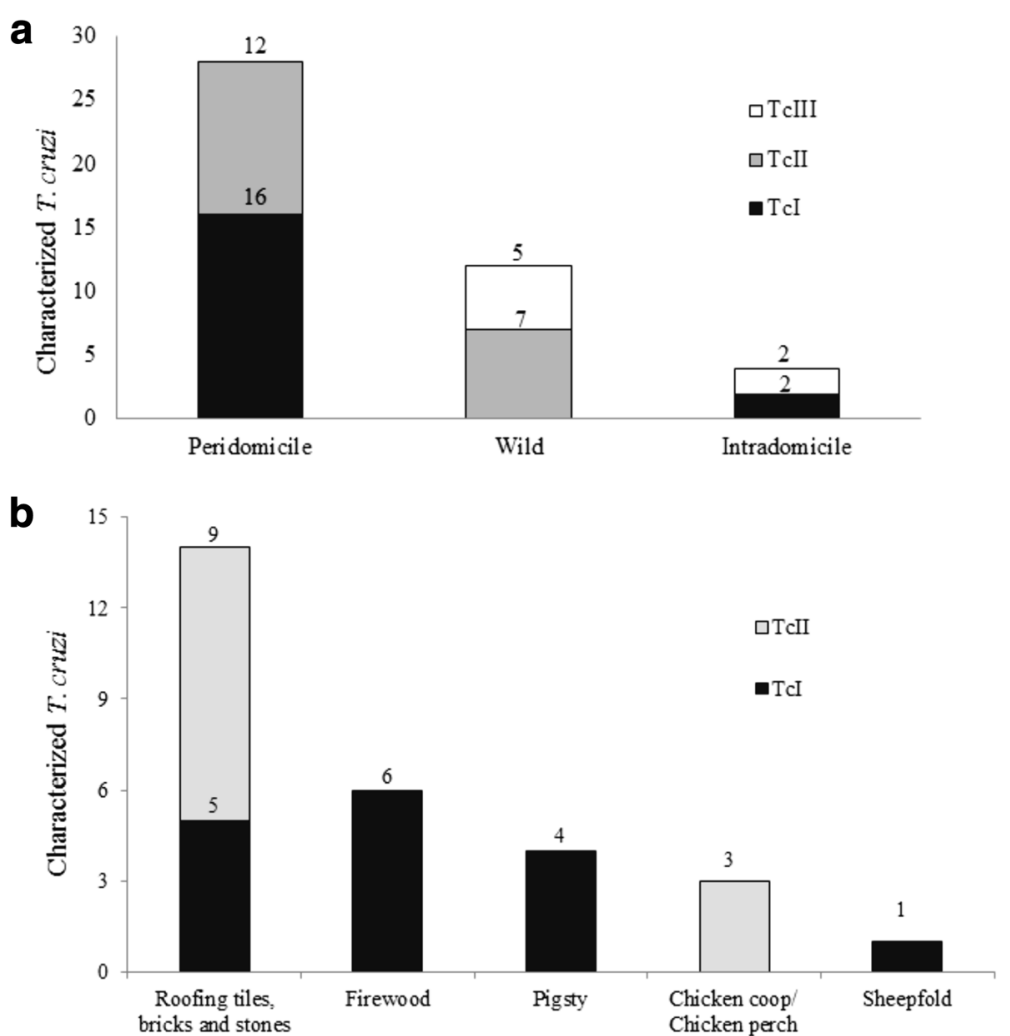

Fig. 2 Prevalence of Trypanosoma cruzi (Tcl: T. cruzi I; Tcll: T. cruzi II; Tclll: T. cruzi III) in Triatoma brasiliensis, T. pseudomaculata and Monodelphis domestica caught in different environments in an area of the Caatinga, Tauá municipality Ceará, Brazil, 2009 to 2015. a Total number of T. cruzi characterized by DTU and environment of origin. $\mathbf{b}$ Characterization of T. cruzi by DTU according to peridomicile ecotopes of origin

diversity of identified food sources includes all groups of animals which were described. The presence of T. brasiliensis in the most diverse peridomicile ecotopes and the variety of food sources confirm its wide distribution and dispersion capacity, mainly in adults. Triatoma infestans females can disperse by walking; such behavior reflects an adaptive strategy to colonize new structures because, unlike flight dispersion, walking allows migration with many eggs in oviducts or dispersion of heavy insects, in good nutritional condition, with difficulty in flying [75]. Furthermore, in this context another possibility for the dispersion of females is the "group" effect [76]. According to this author, the food factor is not the determining factor for migration in females, but rather the reduction of fecundity and oviposition when they are isolated [76].

Nymphs, in turn, presented greater feeding diversity when compared to adult insects, and they showed opportunism and eclecticism. Valença-Barbosa et al. [49] found results similar to the present results regarding the importance of roofing tiles and firewood in peridomicile ecotopes and the detection of DNA of goats in anthropic and wild environments.

A systematic review conducted by Rabinovich et al. [45] indicated that host accessibility is an important factor that shapes the search patterns of blood by triatomines, influenced by the habitats that they colonize. Species which can colonize wild, peridomicile and domestic environments are associated with the more frequent feeding on mammals. For T. brasiliensis, humans and rodents are the main food sources [45].

The distribution of genetic strains in domestic and wild cycles of $T$. cruzi seems to be different, considering the various geographical regions. TcI is widely distributed in the Americas in association with the Didelphidae, and it predominates in the domestic cycles of transmission that occur in the north of Amazon Basin. TcII, TcV and TVI predominate in domestic habitats in the Southern Cone of South America. TcIII and TcIV circulate mainly via wild transmission cycles $[9,10]$.

In Brazil, while the TcII lineages and TcI circulate more abundantly in the wild and domestic environments, respectively, TcIII is usually associated with the wild cycle of the parasite. However, the presence of TcIII in vectors and reservoirs of the domestic cycle is considered to be rare. Thus, studies conducted in Ceará [47, 49, 51], Piauí [72, 77, 78], Rio Grande do Norte [78-80] and Bahia [78] have shown the presence of the strains $\mathrm{TcI}$ and TcIII in the Caatinga, either in triatomines, 


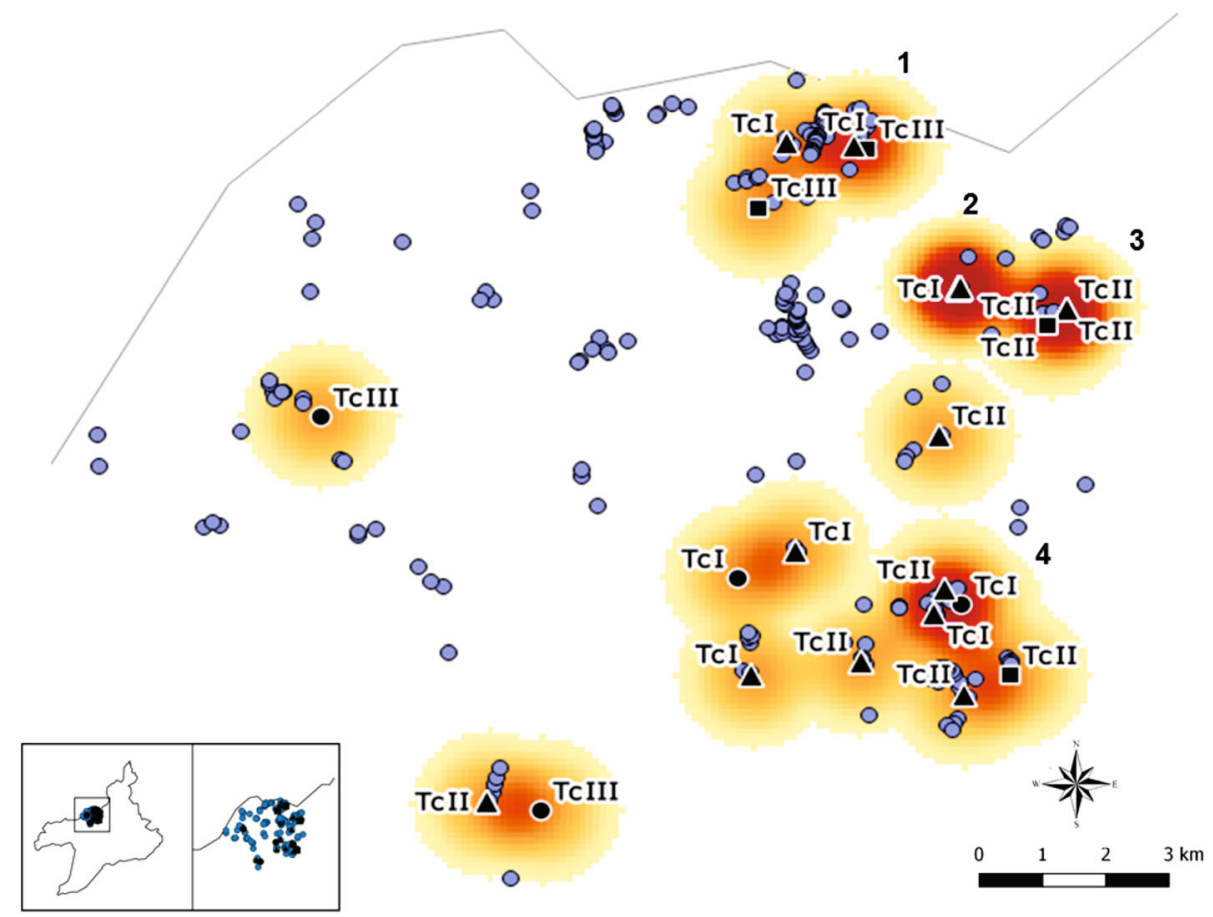

Fig. 3 Map showing the spatial distribution (kernel) of populations of Trypanosoma cruzi characterized in Tauá municipality, Ceará, Brazil, from 2009 to 2015. Blue circles indicate study housing units; black circles indicate intradomicile environments; triangles indicate peridomicile environments; squares indicate wild environments. Abbreviations: Tcl, T. cruzi I; Tcll, T. cruzi II; TcIII, T. cruzi III

mainly T. brasiliensis and P. lutzi, or in wild hosts such as Didelphis albiventris and Thrichomys apereoides laurentius or still in domestic hosts such as dogs, rodents and humans. Camara et al. [80] showed an overlap of TcII-related wild and domestic TcII cycles in T. brasiliensis in Rio Grande do Norte State, as well as their ability to maintain TcII and TcIII in wild cycles and the emerging risk of introduction of these populations in the domestic cycle.

In this study, a sample of TcIII was characterized from Monodelphis domestica caught in the wild environment [47]. Thus, understanding the correlations between DTUs, geographical distribution, habitat, ecology, host species and pathogenicity is still controversial, i.e. the eco-epidemiology of $T$. cruzi is far from being well understood [81].

The occurrence of different DTUs in distinct environments highlights the overlap of wild, peridomicile and intradomicile cycles of $T$. cruzi. The analysis of populations of $T$. cruzi described by environment and time of capture shows that the association of this parasite with T. brasiliensis is wide, and it is present in all periods and ecotopes assessed, as demonstrated by the various clusters evidenced for the wild and anthropic environments. The occupation of land by humans, the indiscriminate use of natural resources and availability of ecotopes in the peridomicile directly intervene in approximation and overlap of wild and domestic cycles of T. cruzi, through the mobility of triatomines and small mammals, such as rodents and marsupials.

In addition, the identification of important peridomicile ecotopes, e.g. roofing tiles, bricks and stones in the study region, is relevant to the development of appropriate strategies for vector control. Thus, the reduction of the colonies of $T$. brasiliensis in this environment can be decisive for a reduction of the intense movement of $T$. cruzi among existing animals. Furthermore, the specificities of the epidemiological profiles of each region and the influence of environmental, socioeconomic and cultural factors should be considered in order to promote successful control initiatives.

\section{Conclusions}

The significant feeding eclecticism of $T$. brasiliensis and its wide circulation between anthropic and domestic environments demonstrate its epidemiological relevance in maintaining the transmission dynamics of T. cruzi in the Caatinga in Ceará. It should be noted that wild, peridomicile and intradomicile cycles of $T$. cruzi may overlap as a result of the association among $T$. brasiliensis, rodents and ruminants, and also because of the presence of $\mathrm{TcI}$ and TcIII in intradomiciles in study region. In this 
context, there is an obvious need to maintain vector control, and successful interventions should consider regional eco-epidemiological differences, regularity and quality of initiatives taken in order to prevent the transmission of $T$. cruzi to humans in the domestic environment.

\section{Additional files}

Additional file 1: The form used in domicile triatomines study. (TIF $1221 \mathrm{~kb}$ ) Additional file 2: Table S1. Number of captured triatomines, examined and parasitized by tripanosomatids, according to capture place, developmental stage in Tauá municipality (CE) from 2009 to 2015. Table S2. Distribution of samples of Triatoma brasiliensis, according to capture place, developmental stage and identification of food source in Tauá municipality (CE), 2015. Table S3. Samples of Triatoma brasiliensis, according to identification of food source, percentage identity and GenBank ID, Tauá municipality (CE), 2015. Table S4. Details of Trypanosomas cruzi samples caracterized in Tauá municipality (CE) from 2009 to 2015. (XLSX 37 kb)

\section{Abbreviations}

BLASTn: Basic local alignment search tool - nucleotide; cox2: Cytochrome oxidase II; HU: Housing unit; IRR: René rachou institute; LIT: Liver infusion tryptose; SESACE: Ceará state health secretariat; SL-IL: Mini-exon intergenic spacer

\section{Acknowledgments}

The authors are thankful for the institutional support provided by the Municipal Department of Health of Tauá, 14th Regional Coordinating Office of Health of Tauá, in Ceará State, and Vector Control Center of the Health Department of Ceará State. The authors would also like to thank the Program for Technological Development in Tools for Health-PDTIS/FIOCRUZ for making their facilities available for this study.

\section{Funding}

WHO / TDR Project A70596, National Council for Scientific and Technological Development (CNPq), René Rachou Institute, Oswaldo Cruz Foundation (Fiocruz-MG), Foundation for Research Support of Minas Gerais State (FAPEMIG), Oswaldo Cruz Foundation - Genomic Platform / PDTIS / FIOCRUZ, Department of Health of Ceará State (SESA-CE).

\section{Availability of data and materials}

The data generated or analyzed in this study are included in this article and its additional files.

\section{Authors' contributions}

All authors substantially contributed to the development of the study. CMB, $S E B, R C M S, R E G$, ANRJ and LD were in charge of the experimental design and data analysis. CMB, SEB and LD collected the insects. CMB, SEB, RCMS and $\mathrm{CPB}$ conducted the experiments. CMB drafted the basic text of the manuscript, with contributions from the other authors. All authors read and approved the final manuscript.

\section{Ethics approval and consent to participate}

Approved by the Chico Mendes Institute for Biodiversity Conservation of the Ministry of the Environment (ICMBio/ME), through the Biodiversity Authorization and Information System (BAIS), process \# 31,693-1 and authentication code 46619742 . The project was submitted to the Animal Ethical Committee of the Federal University of Ceará (protocol 103, October 2011). No human participants were used.

\section{Consent for publication}

Not applicable.

\section{Competing interests}

The authors declare that they have no competing interests.

\section{Publisher's Note}

Springer Nature remains neutral with regard to jurisdictional claims in published maps and institutional affiliations.

\section{Author details}

${ }^{1}$ Universidade Federal do Ceará, Departamento de Saúde Comunitária, Faculdade de Medicina, Fortaleza, CE, Brasil. ${ }^{2}$ Grupo Triatomíneos, Instituto René Rachou, Fundação Oswaldo Cruz, Belo Horizonte, Minas Gerais, Brasil. ${ }^{3}$ Secretaria da Saúde do Estado do Ceará, Fortaleza, CE, Brasil. ${ }^{4}$ Universidad de Buenos Aires, Instituto de Ecología, Genética y Evolución, Buenos Aires, Argentina.

Received: 27 July 2018 Accepted: 26 November 2018 Published online: 17 December 2018

\section{References}

1. Martins-Melo FR, Carneiro M, Ramos AN Jr, Heukelbach J, Ribeiro ALP, Werneck GL. The burden of neglected tropical diseases in Brazil, 1990-2016: a subnational analysis from the Global Burden of Disease Study 2016. PLoS Negl Trop. 2018;12:e0006559.

2. WHO. Chagas disease in Latin America: an epidemiological update based on 2010 estimates Wkly Epidemiol Rec. 2015;6:33-43.

3. Dias JC, Ramos AN Jr, Gontijo ED, Luquetti A, Shikanai-Yasuda MA, Coura JR, et al. 2nd Brazilian Consensus on Chagas Disease, 2015. Rev Soc Bras Med. 2016;49(Suppl. 1):3-60.

4. Hoare CA. The Trypanosomes of Mammals: A Zoological Monograph. Oxford: Blackwell Science Ltd; 1972.

5. Brener Z. Biology of Trypanosoma cruzi. Annu Rev Microbiol. 1973;27:347-82.

6. Devera R, Fernandes O, Coura JR. Should Trypanosoma cruzi be called "cruzi" complex? A review of the parasite diversity and the potential of selecting population after in vitro culturing and mice infection. Mem Inst Oswaldo Cruz. 2003;98:1-12.

7. Garcia ES, Ratcliffe NA, Whitten MM, Gonzalez MS, Azambuja P. Exploring the role of insect host factors in the dynamics of Trypanosoma cruziRhodnius prolixus interactions. J Insect Physiol. 2007:53:11-21.

8. Jansen AM, Roque ALR. Domestic and wild mammalian reservoirs. In: Telleria J, Tibayrenc M, editors. American Trypanosomiasis, Chagas Disease One Hundred Years of Research. London: Elsevier; 2010. p. 249-76.

9. Zingales B, Miles MA, Campbell DA, Tibayrenc M, Macedo AM, Teixeira MM, et al. The revised Trypanosoma cruzi subspecific nomenclature: rationale, epidemiological relevance and research applications. Infect Genet Evol. 2012;12:240-53.

10. Miles MA, Llewellyn MS, Lewis MD, Yeo M, Baleela R, Fitzpatrick $S$, et al. The molecular epidemiology and phylogeography of Trypanosoma cruzi and parallel research on Leishmania: looking back and to the future. Parasitology. 2009;136:1509-28.

11. Marcili A, Lima L, Cavazzana M, Junqueira AC, Veludo HH, Maia Da Silva F, et al. A new genotype of Trypanosoma cruzi associated with bats evidenced by phylogenetic analyses using SSU rDNA, cytochrome $b$ and Histone H2B genes and genotyping based on ITS1 rDNA. Parasitology. 2009;136:641-55.

12. Zingales B, Andrade SG, Briones MR, Campbell DA, Chiari E, Fernandes O, et al. A new consensus for Trypanosoma cruzi intraspecific nomenclature: second revision meeting recommends Tcl to TcVl. Mem Inst Oswaldo Cruz. 2009;104:1051-4.

13. Justi SA, Galvao C. The evolutionary origin of diversity in Chagas disease vectors. Trends Parasitol. 2017;33:42-52.

14. Schofield CJ, Galvao C. Classification, evolution, and species groups within the Triatominae. Acta Trop. 2009;110:88-100.

15. Galvão C. Vetores da doença de chagas no Brasil. Curitiba: Sociedade Brasileira de Zoologia; 2014.

16. Gurgel-Gonçalves R, Galvão C, Costa J, Peterson AT. Geographic distribution of Chagas disease vectors in Brazil based on ecological niche modeling. J Trop Med. 2012;2012:705326.

17. Abad-Franch F, Diotaiuti L, Gurgel-Goncalves R, Gurtler RE. Certifying the interruption of Chagas disease transmission by native vectors: cui bono? Mem Inst Oswaldo Cruz. 2013;108:251-4.

18. Breniere SF, Waleckx E, Barnabe C. Over six thousand Trypanosoma cruzi strains classified into discrete typing units (DTUs): attempt at an inventory. PLoS Negl Trop. 2016;10:e0004792.

19. Silveira AC, Rezende DF. Epidemiologia e controle da transmissão vetorial da doença de Chagas no Brasil. Rev Soc Bras Med. 1994;27:5-16. 
20. Enfermedad de Chagas (tripanosomiasis americana). Organização Panamericana de Saúde. 2006. https://www.paho.org/hq/index.php?option=com_ content\&view=article\&id=5856:2011-informacion-general-enfermedadchagas\&ltemid=40370\&lang=pt. Accessed 17 May 2007.

21. Galvão AB. Triatoma brasiliensis macromelasoma nova subespécie (Reduviidae, Hemiptera). Rev Bras Malariol Doenças Trop. 1956;7:455-7.

22. Lent H, Wygodzinsky P. Revision of the Triatominae (Hemiptera, Reduviidae), and their significance as vectors of Chagas' disease. Bull Am Mus Nat Hist. 1979;163:123-520.

23. Costa J, Maria Argolo A, Felix M. Redescription of Triatoma melanica Neiva \& Lent, 1941, new status (Hemiptera: Reduviidae: Triatominae). Zootaxa. 2006; 1385:47-52.

24. Costa J, Felix M. Triatoma juazeirensis sp. nov. from the state of Bahia, northeastern Brazil (Hemiptera: Reduviidae: Triatominae). Mem Inst Oswaldo Cruz. 2007;102:87-90.

25. Costa J, Correia NC, Neiva VL, Goncalves TC, Felix M. Revalidation and redescription of Triatoma brasiliensis macromelasoma Galvao, 1956 and an identification key for the Triatoma brasiliensis complex (Hemiptera: Reduviidae: Triatominae). Mem Inst Oswaldo Cruz. 2013;108:785-9.

26. Mendonca VJ, Alevi KC, Pinotti H, Gurgel-Goncalves R, Pita S, Guerra AL, et al. Revalidation of Triatoma bahiensis Sherlock \& Serafim, 1967 (Hemiptera: Reduviidae) and phylogeny of the T. brasiliensis species complex. Zootaxa. 2016:4107:239-54.

27. Mendonca VJ, da Silva MT, de Araujo RF, Junior JM, Junior MB, Almeida CE, et al. Phylogeny of Triatoma sherlocki (Hemiptera: Reduviidae: Triatominae) inferred from two mitochondrial genes suggests its location within the Triatoma brasiliensis complex. Am J Trop Med Hyg. 2009;81:858-64.

28. Oliveira J, Marcet PL, Takiya DM, Mendonça VJ, Belintani T, Bargues MD, et al. Combined phylogenetic and morphometric information to delimit and unify the Triatoma brasiliensis species complex and the brasiliensis subcomplex. Acta Trop. 2017;170(Suppl. C):140-8.

29. Forattini OP. Biogeography, origin and distribution of Triatominae domicile dispersal in Brazil. Rev Saude Publica. 1980;14:265-99 (In Portuguese).

30. Alencar JE. História Natural da Doença de Chagas no Estado do Ceará. Fortaleza: UFC; 1987

31. Carcavallo RU, Giron IG, Jurberg J, Lent H. Atlas dos Vetores da Doença de Chagas nas Américas. Rio de Janeiro: Editora Fiocruz; 1997.

32. Borges EC, Dujardin JP, Schofield CJ, Romanha AJ, Diotaiuti L. Dynamics between sylvatic, peridomestic and domestic populations of Triatoma brasiliensis (Hemiptera: Reduviidae) in Ceara State, northeastern Brazil. Acta Trop. 2005;93:119-26.

33. Valenca-Barbosa C, Lima MM, Sarquis O, Bezerra CM, Abad-Franch F. A common Caatinga cactus, Pilosocereus gounellei, is an important ecotope of wild Triatoma brasiliensis populations in the Jaguaribe valley of northeastern Brazil. Am J Trop Med Hyg. 2014;90:1059-62.

34. Costa J, Almeida CE, Dotson EM, Lins A, Vinhaes M, Silveira AC, et al. The epidemiologic importance of Triatoma brasiliensis as a chagas disease vector in Brazil: a revision of domiciliary captures during 1993-1999. Mem Inst Oswaldo Cruz. 2003;98:443-9.

35. Costa J, Dornak LL, Almeida CE, Peterson AT. Distributional potential of the Triatoma brasiliensis species complex at present and under scenarios of future climate conditions. Parasit Vectors. 2014;7:238.

36. Lorenzo MG, Guarneri AA, Pires HH, Diotaiuti L, Lazzari CR. Microclimatic properties of the Triatoma brasiliensis habitat. Cad Saude Publica. 2000; 16(Suppl. 2):69-74 (In Portuguese).

37. Diotaiuti L, MAd O, JPd S, Barbosa SE. Triatomíneos. Belo Horizonte: Rede de Bibliotecas da Fiocruz; 2015.

38. Catala S, Bezerra CM, Diotaiuti L. Thermal preferences and limits of Triatoma brasiliensis in its natural environment-field observations while host searching. Mem Inst Oswaldo Cruz. 2015;110:793-6.

39. Forattini OP, Barata JM, Santos JL, Silveira AC. Feeding habits, natural infection and distribution of domiciliary Triatomidae in the northeast region of Brazil. Rev Saude Publica. 1981;15:113-64 (In Portuguese).

40. Schofield CJ, Diotaiuti L, Dujardin JP. The process of domestication in Triatominae. Mem Inst Oswaldo Cruz. 1999;94(Suppl. 1):375-8.

41. Silveira AC, Vinhaes MC. Elimination of vectorial transmission of Chagas disease in Brazil. Medicina. 1999:59(Suppl. 2):97-102 (In Portuguese).

42. Diotaiuti L, Faria Filho OF, Carneiro FC, Dias JC, Pires HH, Schofield CJ. Operational aspects of Triatoma brasiliensis control. Cad Saude Publica. 2000; 16(Suppl. 2):61-7 (In Portuguese).
43. Sarquis O, Carvalho-Costa FA, Toma HK, Georg I, Burgoa MR, Lima MM. Ecoepidemiology of Chagas disease in northeastern Brazil: Triatoma brasiliensis, T. pseudomaculata and Rhodnius nasutus in the sylvatic, peridomestic and domestic environments. J Parasitol Res. 2012;110:1481-5.

44. Schofield CJ. Nutritional status of domestic populations of Triatoma infestans. Trans R Soc Trop Med. 1980;74:770-8.

45. Rabinovich JE, Kitron UD, Obed Y, Yoshioka M, Gottdenker N, Chaves LF. Ecological patterns of blood-feeding by kissing-bugs (Hemiptera: Reduviidae: Triatominae). Mem Inst Oswaldo Cruz. 2011;106:479-94.

46. Costa J, de Almeida JR, Britto C, Duarte R, Marchon-Silva V, Pacheco Rda S. Ecotopes, natural infection and trophic resources of Triatoma brasiliensis (Hemiptera, Reduviidae, Triatominae). Mem Inst Oswaldo Cruz. 1998;93:7-13.

47. Bezerra CM, Cavalcanti LP, Souza Rde C, Barbosa SE, Xavier SC, Jansen AM, et al. Domestic, peridomestic and wild hosts in the transmission of Trypanosoma cruzi in the Caatinga area colonised by Triatoma brasiliensis. Mem Inst Oswaldo Cruz. 2014;109:887-98.

48. Sarquis O, Carvalho-Costa FA, Oliveira LS, Duarte R, PS DA, de Oliveira TG, et al. Ecology of Triatoma brasiliensis in northeastern Brazil: seasonal distribution, feeding resources, and Trypanosoma cruzi infection in a sylvatic population. J Vector Ecol. 2010;35:385-94.

49. Valenca-Barbosa C, Fernandes FA, Santos HL, Sarquis O, Harry M, Almeida $C E$, et al. Molecular identification of food sources in triatomines in the Brazilian northeast: roles of goats and rodents in Chagas disease epidemiology. Am J Trop Med Hyg. 2015;93:994-7.

50. Almeida CE, Vinhaes MC, de Almeida JR, Silveira AC, Costa J. Monitoring the domiciliary and peridomiciliary invasion process of Triatoma rubrovaria in the State of Rio Grande do Sul, Brazil. Mem Inst Oswaldo Cruz. 2000;95:761-8.

51. Lima MM, Sarquis O, de Oliveira TG, Gomes TF, Coutinho C, Daflon-Teixeira $N F$, et al. Investigation of Chagas disease in four periurban areas in northeastern Brazil: epidemiologic survey in man, vectors, non-human hosts and reservoirs. Trans R Soc Trop Med. 2012;106(3):143-9.

52. IPECE. Perfil Básico Municipal de Tauá 2016. Fortaleza: Instituto de Pesquisa e Estatística Econômica do Ceará; 2016.

53. VPV O. A problemática da degradação dos recursos naturais no domínio dos sertões secos do Estado do Ceará-Brasil. In: Silva JB, EWC D, Zanella ME, AJA M, editors. Litoral e Sertão - natureza e sociedade no nordeste brasileiro. Fortaleza: Expressão Gráfica; 2006. p. 446.

54. BRASIL. Manual de normas técnicas da campanha de controle da doença de Chagas. Brasília: Ministério da Saúde; 1980. p. 167.

55. Bronfen E, Rocha FSA, Machado GBN, Perillo MM, Romanha AJ, Chiari E. Isolamento de amostras do Trypanosoma cruzi por xenodiagnóstico e hemocultura de pacientes na fase crônica da doença de Chagas. Mem Inst Oswaldo Cruz. 1989;84:237-40.

56. Kitano T, Umetsu K, Tian W, Osawa M. Two universal primer sets for species identification among vertebrates. Int J Legal Med. 2007;121:423-7.

57. Vallejo GA, Guhl F, Chiari E, Macedo AM. Species specific detection of Trypanosoma cruzi and Trypanosoma rangeli in vector and mammalian hosts by polymerase chain reaction amplification of kinetoplast minicircle DNA. Acta Trop. 1999;72:203-12.

58. D'Avila DA, Macedo AM, Valadares HM, Gontijo ED, de Castro AM, Machado $\mathrm{CR}$, et al. Probing population dynamics of Trypanosoma cruzi during progression of the chronic phase in chagasic patients. J Clin Microbiol Infect. 2009;47:1718-25.

59. Souto RP, Fernandes O, Macedo AM, Campbell DA. Zingales B. DNA markers define two major phylogenetic lineages of Trypanosoma cruzi. Mol Biochem Parasitol. 1996;83:141-52.

60. de Freitas JM, Augusto-Pinto L, Pimenta JR, Bastos-Rodrigues L, Goncalves VF, Teixeira SM, et al. Ancestral genomes, sex, and the population structure of Trypanosoma cruzi. PLoS Pathog. 2006;2:e24.

61. Burgos JM, Altcheh J, Bisio M, Duffy T, Valadares HM, Seidenstein ME, et al. Direct molecular profiling of minicircle signatures and lineages of Trypanosoma cruzi bloodstream populations causing congenital Chagas disease. Int J Parasitol. 2007:37:1319-27.

62. Câmara G, Carvalho MS. Análise espacial de eventos. In: Druck S, Carvalho MS, Câmara G, Monteiro AVM, editors. Análise Espacial de Dados Geográficos. Brasília: EMBRAPA; 2004. p. 31-45.

63. Barretto MP, Ribeiro RD. Reservatórios silvestres do Trypanosoma (Schizotrypanum) cruzi, Chagas 1909. Rev Inst Adolfo Lutz. 1979;39:25-36.

64. Noireau F, Carbajal-de-la-Fuente AL, Lopes CM, Diotaiuti L. Some considerations about the ecology of Triatominae. An Acad Bras Cienc. 2005;77:431-6. 
65. Fernandes AJ, Vitor RW, Dias JC. Parasitologic and serological evaluation of caprines experimentally inoculated with Trypanosoma cruzi. Rev Inst Med Trop São Paulo. 1994;36:11-7 (In Portugese).

66. Jansen AM, Leon L, Machado GM, da Silva MH, Souza-Leao SM, Deane MP. Trypanosoma cruzi in the opossum Didelphis marsupialis: parasitological and serological follow-up of the acute infection. Exp Parasitol. 1991;73:249-59.

67. Jansen AM, Madeira FB, Deane MP. Trypanosoma cruzi infection in the opossum Didelphis marsupialis: absence of neonatal transmission and protection by maternal antibodies in experimental infections. Mem Inst Oswaldo Cruz. 1994;89:41-5.

68. Bosseno MF, Garcia LS, Baunaure F, Gastelum EM, Gutierrez MS, Kasten FL, et al. Identification in triatomine vectors of feeding sources and Trypanosoma cruzi variants by heteroduplex assay and a multiplex miniexon polymerase chain reaction. Am J Trop Med Hyg. 2006;74:303-5.

69. Gurtler RE, Cardinal MV. Reservoir host competence and the role of domestic and commensal hosts in the transmission of Trypanosoma cruzi. Acta Trop. 2015;151:32-50.

70. Almeida CE, Faucher L, Lavina M, Costa J, Harry M. Molecular individualbased approach on Triatoma brasiliensis: Inferences on triatomine foci, Trypanosoma cruzi natural infection prevalence, parasite diversity and feeding sources. PLoS Negl Trop. 2016;10:e0004447.

71. Gurtler RE, Cecere MC, Petersen RM, Rubel DN, Schweigmann NJ. Chagas disease in north-west Argentina: association between Trypanosoma cruzi parasitaemia in dogs and cats and infection rates in domestic Triatoma infestans. Trans R Soc Trop Med. 1993;87:12-5.

72. Herrera L, D'Andrea PS, Xavier SC, Mangia RH, Fernandes O, Jansen AM. Trypanosoma cruzi infection in wild mammals of the National Park 'Serra da Capivara' and its surroundings (Piaui, Brazil), an area endemic for Chagas disease. Trans R Soc Trop Med. 2005;99:379-88.

73. Oliveira-Lima JW, Faria Filho OF, Vieira JB, Gadelha FV, Oliveira Filho AM. Peridomiciliary changes and implications for Triatoma brasiliensis control. Cad Saude Publica. 2000;16(Suppl. 2):75-81 (In Portuguese).

74. Cecere MC, Vazquez-Prokopec GM, Gurtler RE, Kitron U. Spatio-temporal analysis of reinfestation by Triatoma infestans (Hemiptera: Reduviidae) following insecticide spraying in a rural community in northwestern Argentina. Am J Trop Med Hyg. 2004;71:803-10.

75. Abrahan LB, Gorla DE, Catala SS. Dispersal of Triatoma infestans and other Triatominae species in the arid Chaco of Argentina: flying, walking or passive carriage? The importance of walking females. Mem Inst Oswaldo Cruz. 2011;10:232-9.

76. Ceballos Perazzi NS. Comunicación química en el reino animal. Efecto del grupo en la oviposición de hembras de Triatoma infestans Klug, 1834 (Hemiptera: Reduviidae). Argentina: Seminario II, Universidad Nacional de Córdoba; 1985. p. 10

77. Araujo CA, Waniek PJ, Xavier SC, Jansen AM. Genotype variation of Trypanosoma cruzi isolates from different Brazilian biomes. Exp Parasitol. 2011;127:308-12.

78. Marcili A, Lima L, Valente VC, Valente SA, Batista JS, Junqueira AC, et al. Comparative phylogeography of Trypanosoma cruzi TCllc: new hosts, association with terrestrial ecotopes, and spatial clustering. Infect Genet Evol. 2009;9:1265-74

79. Camara AC, Varela-Freire AA, Valadares HM, Macedo AM, D'Avila DA, Machado CR, et al. Genetic analyses of Trypanosoma cruzi isolates from naturally infected triatomines and humans in northeastern Brazil. Acta Trop. 2010;115:205-11.

80. da Camara AC, Lages-Silva E, Sampaio GH, D'Avila DA, Chiari E, da Cunha Galvao LM. Homogeneity of Trypanosoma cruzi I, II, and III populations and the overlap of wild and domestic transmission cycles by Triatoma brasiliensis in northeastern Brazil. J Parasitol Res. 2013;112:1543-50

81. Dario MA, Rodrigues MS, Barros JH, Xavier SC, D'Andrea PS, Roque AL, et al. Ecological scenario and Trypanosoma cruzi DTU characterization of a fatal acute Chagas disease case transmitted orally (Espirito Santo State, Brazil). Parasit Vectors. 2016;9:477.

\section{Ready to submit your research? Choose BMC and benefit from:}

- fast, convenient online submission

- thorough peer review by experienced researchers in your field

- rapid publication on acceptance

- support for research data, including large and complex data types

- gold Open Access which fosters wider collaboration and increased citations

- maximum visibility for your research: over $100 \mathrm{M}$ website views per year

At BMC, research is always in progress.

Learn more biomedcentral.com/submissions 